https://doi.org/10.18485/iipe_response2covid19.2021.ch18

\title{
JAPAN AND SOUTH KOREA'S POLICY IN RESPONSE TO COVID-19: A COMPARATIVE PERSPECTIVE
}

\author{
Olga Barbasiewicz ${ }^{1}$ \\ Agnieszka Pawnik²
}

\begin{abstract}
The similarities and differences in the South Korean and Japanese approaches to the pandemic response have been compared since the first cases were registered in both countries. South Korea became a famous example of how to deal with the outbreak effectively, despite the concerns about the aggressive methods of gathering data about its citizens. The Japanese government has been dealing with criticism concerning its management of the Tokyo Olympics, the COVID-19 response, economic countermeasures, and the slow vaccination rollout. This paper offers a brief analysis of the questions of how and what is influencing both governments and what makes an efficient response to the crisis of this scale.
\end{abstract}

Keywords: COVID-19, Tokyo Olympics, Moon Jae-In, Japan-Korean relations.

2020 was the year when the Japanese government planned to make its great comeback to world politics by organizing the "Tokyo 2020 Olympic Games". The great enthusiasm, followed by years of preparation on the Japanese side, was stopped by the outbreak of the COVID-19 pandemic. Starting with the People's Republic of China (China), many countries have suffered from numerous cases of the coronavirus among their citizens. Among them were Japan and the Republic of Korea (ROK/Korea $\left.{ }^{3}\right)$.

The importance of standing against this new disease was emphasized by Korean President Moon Jae-in during his speech on the occasion of commemorating the March $1^{\text {st }}$ Movement (First Independence Movement Day). Dealing with the memory

\footnotetext{
1Jagiellonian University, Poland, obarbasiewicz@gmail.com.

${ }^{2}$ Independent researcher, Poland, agnieszka.pawnik@wp.pl.

${ }^{3}$ The authors are going to use the short form Korea, mentioning the Republic of Korea/South Korea.
} 
of the anti-Japanese uprising, he announced that: "(...) We will be able to overcome the COVID-19 outbreak and revive our shrunken economy. (...) The government has started providing support tailored to microbusiness owners and SMEs, as well as various service industries such as tourism, dining, and air and maritime transport. In addition to the provision of stronger support for overcoming the damage, a support package to respond to the COVID-19 outbreak will be swiftly implemented. These contain unprecedented plans to stabilize the livelihood of ordinary people and enhance economic vitality. (...) By overcoming the pressing COVID-19 outbreak at home and achieving peace and common prosperity on the Korean Peninsula, we will build a Republic of Korea that cannot be shaken. That is genuine independence and the completion of a new independence" (Address by President Moon Jae-in on the 101st March First Independence Movement Day, 2020).

Meanwhile, the Japanese Prime Minister, Abe Shinzō, mentioned that the danger of COVID-19 was coming to Japan, but it was still not that hard as in Korea. He calmed: "We will do everything possible to minimize that burden by putting into place, to the greatest possible extent, measures to provide care for small children. The government will do everything possible to support local government efforts, including making the same arrangements at after-school care programs as during spring break. We also intend to establish a new grant scheme to squarely address the reduction in income resulting from parents taking leaves of absence from work, for both permanent and non-permanent workers. As the one who made that decision, taking full responsibility, I am determined to thoroughly address the various issues that arise. We will also swiftly compile within roughly the next 10 days a second emergency policy package that utilizes this fiscal year's contingency funds, which amount to more than 270 billion yen" (Press Conference by the Prime Minister, 2020). A few days later, a special state of emergency was introduced in Japan, and 6 months later, Abe resigned.

In this article, the authors decided to raise the case of the governmental response to COVID-19 in both countries. Since the Japanese-Korean relations in the times of the pandemic were examined by Justyna Filipowicz (Filipowicz, 2021), we claim that the pandemic became a moment that, instead of showing the new, modern role of Japan, created a severe crisis in internal politics and revealed the features that were attempted to be solved, such as the isolation of Japan. In the case of South Korea and its specific approach towards the policies that ruled over the pandemic response, multiple internal and external factors were at play, including the topic of privacy of its citizens, previous experience gained during the SARS outbreak in 2015, and relations with its neighbours.

Therefore, we ask: What were the first measures taken by both governments when the pandemic started? What is the impact of the governments' COVID-19 
strategy on the political moods in Japan and Korea? But the deepest analysis is devoted to answering the questions: What is the vaccination program in both countries, and how is it implemented? What is the current course and major challenges of the vaccination process in both countries? This structure will help to understand the complex aspects of the anti-COVID-19 strategy of each country and its results.

\section{JAPANESE AND KOREAN REACTIONS TO THE COVID-19 OUTBREAK}

At the beginning of the pandemic, Japan decided not to allow foreigners to come to Japan. The residents of Japan were also included in this order. That meant that the people who had their families in Japan were not able to return to the country. Moreover, foreigners who were abroad were not able to come back to their homes and workplaces. Blaming non-nationals for the COVID-19 spikes was also reported by the media (Kyodo News, 2020). After a few months, the voices claiming that non-Japanese residents should be able to enter Japan have become stronger (Osumi, 2020). Nonetheless, Japan continues to request visa applications, even from nationals of nations that were granted visa-free admission to Japan prior to March 2020.

In Korea, the country where, at the very beginning of the pandemic, COVID-19 came from China, openness and social trust became the keys to success (Osumi, 2020). The data analysis and testing system became the reason for avoiding the situation as it was at the beginning in China. Similarly to the situation in Japan, tourists are not allowed to come to Korea, and all the applicants that were able to participate in the visa-free program are now asked to have this document. The situation with non-Korean residents was slightly different to this in Japan, but discrimination cases still happened. For example, non-Korean residents could not benefit from governmental economic help during the COVID crisis. The local authorities managed to change it in Seoul but not in, for example, Gyeonggi, where the population of foreigners is quite large (Ester, 2020).

\section{THE TOKYO OLYMPICS 2020 - THE MOMENT JAPAN WANTED TO COME BACK}

Although both countries suffered from COVID-19, they were not only dealing with the virus but also with the lack of tourism. Japan lost even more - the opportunity to show that it is back on the international stage by organizing the Olympic Games. By hosting the Olympic Games in the 21st century, Japan hoped to use its so-called soft power. The idea was to draw the international audience's attention to the high level of robotization or popular culture. Japanese politicians 
remembered well the Chinese promotional success during the 2008 Olympics. However, they were aware of the People's Republic of China's dominant economic role in Asia. Japan is gradually losing its economic importance. Hosting the Olympic Games was the moment the country wanted to demonstrate its comeback, presenting Japan as a modern country operating according to Western standards, with recognizable and desirable culture and technology around the world.

However, the organization of the Games was associated with high levels of public discontent and protests across political camps. According to a May 2021 "Asahi Shimbun" public opinion poll, 83\% of people surveyed were against holding the event (Asahi Shimbun, 2021). Eventually, the government decided to hold the Olympics without the presence of fans - including those from Japan.

\section{THE COVID-19 VACCINATION PROGRAM IN JAPAN AND SOUTH KOREA}

South Korean and Japanese approaches to the pandemic have been compared since the first cases were registered in both countries. South Korea was both praised and criticized for its aggressive methods of gathering data about its citizens, which eventually led to some concerns voiced by the Human Rights Commission (Byoungil Oh, Yeokyung Chang and SeonHwa Jeong, 2020). But according to the prognosis made by the OECD, in the same period, the country accomplished a great economic victory - its GDP was estimated to decrease only by $0.8 \%$ in 2020 , significantly less than Japan's GDP, which was lowered by 6\% (Ujek, 2021). The Japanese approach, especially now when the vaccination processes are being rolled out, has been put under scrutiny by the domestic political opposition and many international experts.

Despite a significant acceleration in the vaccination process, the world's thirdlargest economy does not fare well in terms of the number of fully vaccinated citizens. As of July 6, 2021, Japan has vaccinated $14.5 \%$ of its population, just 4 percentage points above the global average. By comparison, Poland has $36.7 \%$ of its citizens vaccinated (Our World in Data, 2021). Japan also compares particularly poorly with other G7 countries, with the United Kingdom having over $50 \%$ of its population vaccinated, the United States at 48\%, Germany at 39\%, Canada at 38\%, France and Italy at 34\% (New York Times, 2021). At the same time, as of July 15, South Korea has $11.4 \%$ of its population fully vaccinated, which translates to roughly 5.87 million people who have received both doses and 20.3 million people who were vaccinated with at least one dose. The South Korean population is roughly 51 million people, whereas Japan's is 126 million people.

The Olympic Games, scheduled to take place in Tokyo on July 23, 2021, are a very powerful catalyst to highlight the Japanese government's efficiency and decision-making during the pandemic. The biggest concern among Japanese citizens 
is precisely the safety rules associated with it. In late June 2021, the Tokyo council under the Ministry of Health warned of another wave of mass infections. Between June 24 and July 6, the level of new cases in Tokyo remained at about 570 cases per day. In the week from June 17 to 24, it was 452 cases, and the week before, it was 386 (Japan Times, 2021).

The Olympics are accompanied by a significant acceleration of the mass vaccination process, but they encounter a number of structural problems. As late as June 18 , more than 6,000 people involved in the organizational activities of the event queued up for vaccination (Pawnik, 2021). By the end of June, one in two Japanese aged 65 and over had received at least one dose of the vaccine, but only since June 21 have they been available to younger people, not excluding athletes representing Japan at the Olympics (Steem, 2021).

On the other hand, the South Korean government is struggling with criticism as well. By April 2021, Seoul secured vaccines for 99 million people, almost twice the total number of its population and more than 2.5 times the intended target for the country's immunity. (Shin, 2021). However, the ambitious plans for the first half of 2021 were not met - the original goal of vaccinating $20 \%$ of the population in July has failed. The young workers of the companies, who are working and interacting with each other daily, with little to no remote working solutions at all, are often pointed out as a reason for the fluctuating numbers of cases and are unlikely to get vaccinated anytime soon (Shin, 2021).

On July 14, South Korea registered more than 1.600 new cases to the toll of 174 thousand people and 2 more deaths, which rounds up the number of fatal infections to a little bit more than 2 thousand people. This marks the $7^{\text {th }}$ consecutive day of cases involving more than 1.000 cases daily (SangmiChaHyonhee, 2021). Despite the relatively high numbers of cases, especially compared to the beginning of the pandemic, a great majority of people who contracted COVID-19 in South Korea survived - the highest death toll registered on July 14 was 982 people in Indonesia, 791 in Russia, and 230 in Mexico. All of these countries, however, register substantially more sick people every day- Indonesia more than 50 thousand people, and Mexico more than 12 thousand (Our World in Data, 2021).

The situation in South Korea is becoming more and more complicated. More than 1.67 million people aged from 55 to 59 have been put on hold for a week due to the shortages and the crashes of the governmental websites used for the online application processes. The country deals with shortages of jabs and the highest ever daily increase in cases (SangmiChaHyonhee, 2021).

This article hopes to outline the major logistical and structural problems that are slowing down the mass vaccination process in Japan and in South Korea, with 
a particular focus on the process of large corporations taking a more prominent role in it.

\section{THE COURSE AND MAJOR CHALLENGES OF THE VACCINATION PROCESS IN JAPAN AND SOUTH KOREA}

Among the biggest obstacles to mass vaccination in Japan are slow decisionmaking processes in approving vaccines for use. Japanese laboratories have been testing the performance of Moderna and Pfizer vaccines since late January 2021. In the first half of February, Japan confirmed the efficacy and safety of the Pfizerbranded formulation and began testing processes for the AstraZeneca vaccine. Despite this, the vaccination process for citizens over the age of 65 only began in April. Before that, health care workers stood in queues to receive a jab.

AstraZeneca was approved for use in May, but the vaccine process was stopped the same day due to concerns about side effects. On May 24, Japan also opened mass vaccination centres in Tokyo and Osaka (SangmiChaHyonhee, 2021). Local government structures and the Self-Defense Forces are responsible for administering vaccines in Japan. According to the Japanese Ministry of Health, the country "hopes" to complete the vaccination process for "citizens who are willing to receive the vaccines" in November 2021 (SangmiChaHyonhee, 2021).

Another significant factor slowing down the vaccination process is Japanese law. Until the amendment of the Immunization Act (予防接種法) in 1994, Japanese citizens were obliged to be vaccinated (Mainichi News, 2021), but later the law mentioned a "commitment of effort" to obtain the vaccine (Immunization Act, 1994). The amendment came as a result of a series of lawsuits for compensation due to side effects after receiving Japanese MMR preparations decided in favour of the victims. In 2010, there was another series of vaccine controversies, this time against the HPC virus, which was included in the National Vaccine Program until 2013. As a result, demand for domestic production fell sharply, the government stopped supporting the development of new formulations, and large pharmaceutical companies withdrew from the market. Thus, campaigns to popularize vaccination in Japan on the same scale as before ceased (Bohorodycz, 2021).

Japan, which is sometimes referred to as the world's only "super-ageing" society, faces a number of challenges in vaccinating a population nearly $30 \%$ of which is 65 years old or older (D'Ambrogio, 2020). As of early July, nearly half of Japan's 36 million seniors have received at least one dose of the vaccine. Here, the logistical problems of enrolling and administering the vaccine to people with varying degrees of mobility and access to the Internet come into play but also citizens' anxiety about the safety of the available products (Mainichi News, 2021). 
Beata Bochorodycz cites an Ipsos survey conducted with the World Economic Forum in late January 2021, during which $64 \%$ of Japanese respondents were willing to be vaccinated. This was the third-lowest result among the countries surveyed, just ahead of France and Russia, which registered $57 \%$ and $42 \%$ willingness, respectively (Bochorodycz, 2021).

During the first wave of the pandemic, South Korea's approach based on mass testing and a relatively liberal policy toward lockdown was successful. The government did not close its borders and loudly criticized its Japanese neighbour for doing so (Pawnik, 2020). The clusters were highly localized, including the infamous case of patient 31, a member of the Shincheonji church, who is sometimes described as a "superspreader". To tackle this, the South Korean government decided to reach for the data stored on the security cameras, online banking documents, and data stored on the personal phones of its citizens (Pawnik, 2020).

South Korea approved the usage of the vaccines by Pfizer, AstraZeneca, Novavax and Janssen by April 2021 and quickly reached its daily vaccination targets. However, shortages and infrastructural obstacles have led to a sharp decrease in the daily doses, from 850.000 to less than 30.000 daily. Around 13 July, the government cited the non-disclosure agreements to avoid giving a certain date of the next arrival of the Moderna vaccine (SangmiChaHyonhee, 2021).

As it was mentioned before, the infections have become gradually less severe with more and more of the older and more vulnerable groups being fully vaccinated. The concern lies within the groups of younger people, mostly employed by companies and large corporations. According to the governmental data from 12 July, $63 \%$ of the cases in this particular group were connected to the Delta variant (SangmiChaHyonhee, 2021).

The slow rollout of the vaccines in South Korea is often attributed to the success of the first wave's management. Perhaps the sense of urgency felt by the politicians of the United States, the United Kingdom or the European Union was not shared by Seoul, which registered far fewer confirmed cases than the world's average. According to the government data accessed on 15 July, the positivity rate of the confirmed cases in South Korea is now 1.6\%, while other countries, such as the United States, register roughly 10\% (Ministry of Health of South Korea, 2021). However, it is a major and worrying increase from the statistics from April 2021, when the rate was around 0.002\% (SangmiChaHyonhee, 2021).

\section{'JAPAN INC.' AND THE KOREAN ECONOMY IN THE MIDST OF A PANDEMIC}

In response to protracted vaccination processes, more and more Japanese corporations are choosing to provide vaccines to their employees. On 21 June 2021, 
the government issued official permits to companies such as Toyota Motor, SoftBank Group and Nomura Hold. to dispense Moderna vaccine doses to employees inside their offices (Strait Times, 2021).

This unprecedented private sector involvement in Japan is winning more supporters. Tokyo-based oil company Eneos Holdings, Aeon and one of Japan's most popular clothing chains, Uniqlo, have also expressed interest in employee vaccination programs. As of the second half of June, 3,419 Japanese companies employing a total of 13.7 million people had signed up for the program, according to The Straits Times (2021).

All of this is causing the term "Japan Inc." to resurface in the Japanese and foreign press, this time in the context of taking over processes to prevent further spread of the COVID-19 pandemic. The sentiment of "Japan Inc.", a combination of the Japanese government and business structures, made its way into the literature in the 1980s (Drucker, 1981). Over the years, it has also been used to describe the role of Japanese companies at the world's industrial forefront. "Japan Inc." is usually paired with a description of Japanese business culture in an attempt to answer the question of why distinctive hierarchical rules or rigid rules of etiquette and language survive in Japanese corporations.

Here, however, further structural problems and slower decision-making processes emerge. Despite strong interest from Japanese small and medium-sized enterprises, which account for $99.7 \%$ of all companies in Japan (独立行政法人中 小企業基盤整備機構, 2021), the office vaccination program targets only large entities. In response, some Japanese startups have begun to unite so as to meet the government requirements (Straits Times, 2021).

As of 15 July, South Korea does not have a similar program available - instead, it is focusing on the largest players, crucial to the economy, such as the Samsung Group, LG and semiconductor company SK Hynix Inc. These representatives of the South Korean private sector are helping to ramp up the vaccination program by offering employees a jab of the Moderna vaccine at the end of June 2021. This initiative is being monitored closely by the Ministry of Labour, which is responsible for assessing the needs of the companies (Telecom, 2021).

Supporters of the program hope that peer and supervisor pressure will help encourage hesitant younger corporate employees. Both Japanese and Korean office workers are reluctant to change jobs, and companies tend to hire employees for their entire careers, so many people rely on their workplace for health care and periodic check-ups. Vaccines issued in offices are somewhat of an extension of these features of Japanese and South Korean work culture. 
This would prove especially useful in the case of the South Korean office workers, often considered to be the main spreaders, despite being at the back of the lines for the vaccines. Unless listed in the vulnerable category, only teachers, social workers, and workers at high-risk facilities are eligible for the jab outside of the queue.

Japanese citizens clearly show that they are not satisfied with the policy led by the ruling Liberal Democratic Party of Japan (LDP). In September 2020, the longestserving Prime Minister, Abe Shinzō, resigned. The new political leader of Japan, Suga Yoshihide, failed to halt declining support for the ruling party.

The biggest test was the recent local elections in Tokyo. If the LDP does not win outright, it risks losing power to KoikeYuriko, whose local party Tokyo Citizens First won 31 seats in Tokyo at the beginning of July (Kyodo News, 2021). Prime Minister Abe was losing support in June and July 2020, when the Olympic Games were planned to start. Half of the respondents did not support his policy at that time (Asahi Shimbun, 2020). After Suga became Prime Minister, the social moods showed some optimism in the opinion pools, only to fall suddenly to $47 \%$ in May and $42 \%$ in June of respondents who did not support Suga's policy (Asahi Shimbun, 2020).

In Korea, the situation is quite similar, with voices of dissatisfaction - but in the case of this country, it is caused by the housing policy, which is unpopular among Koreans. Support for President Moon Jae-in is at an all-time low of 34.1\%, and support for his Democratic Party is also very low, reaching 32\% (Hallup, 2021). The opinion of Koreans on governmental reaction to COVID-19 was critical even in March 2020 . At that time, $56 \%$ of respondents were against the governmental policy in this matter.

\section{CONCLUSION}

Korea and Japan were some of the first countries to which the coronavirus spread from China. We can analyze Korea in the context of the country's help to business, but the vaccination program in the case of Japan, as one of the important aspects, was postponed because of the 2020 Olympic Games. The moment when Japan decided to "come back" was the moment when the ruling party lost support and was waiting for the results of the Autumn Elections. The anti-Olympic mood of Japanese citizens is a serious difficulty for the COVID-19 struggle of the Japanese government, which is still under the criticism of a large part of the nation. Even though the international corporations, both Japanese and Korean, help with the vaccination process, the speed cannot be compared to the one in Europe in the case of Japan. The vaccines which are allowed in the Country of the Rising Sun are only Pfizer and Moderna, while Korea uses four different types of vaccines, making 
the pace faster compared to Japan. Moreover, the big blow was the closure of the countries which disabled tourists to visit Japan and Korea that benefit from the tourist movement. The "come back" to the regular visitors' exchange will be a long and hard process in the post-COVID world, which can be challenging and healing for Japan and Korea.

\section{REFERENCES}

Address by President Moon Jae-in on 101st March First Independence Movement Day,retrieved from http://english1.president.go.kr/BriefingSpeeches/Speeches/ 768. Accessed 15 July 152021.

Asahi Shimbun (2021). Yoronchousa, retrieved from https://www.asahi.com/ politics/yoron/. Accessed 7 July2021.

Asahi Shimbun (2021/04). Survey: 83\% against holding Tokyo Olympics this summer, retrieved from http://www.asahi.com/ajw/articles/14351670. Accessed 4 July2021.

Bochorodycz, B. (2021) Japonia wobec wyzwań zwiqzanych z COVID-19:Ku strategicznej i niestrategicznej współpracy [Japan vs. the challenges of COVID19: Towards the strategic and non-strategic cooperation].AMU Faculty of Political Science and Journalism.

Byoung-il Oh, Yeokyung Chang and SeonHwa Jeong (2020). COVID-19 and the Right to Privacy: An analysis of South Korean experiences, Korean Progressive Network Jinbonet and Institute for Digital Rights, full report available at https://www.apc.org/en/pubs/covid-19-and-right-privacy-analysis-southkorean-experiences. Accessed 4 July2021.

D’Amborgio, E. (2020). Japan's ageing society. Briefing: Continental democracies. European Parliement, December 2020.

Drucker, P. F. (1981).Behind Japan's Success. Harvard Business Review, 1981. Retrieved from https://hbr.org/1981/01/behind-japans-success. Accessed 6 July 2021.

Filipowicz, J. (2021), "South Korean-Japan Bilateral Relations in the Times of COVID19 (pp. 63-82 )". In Barbasiewicz O., Pletnia M,Internal and External Aspects of Japanese Security. Bern, Switzerland.

Gallup (2021/07). Moon's approval rating dives to all-time low of 34 pct, retrieved fromhttps://en.yna.co.kr/view/AEN20210326010400315. Accessed 7 July 2021.

Im, E. S. (2020/12).How Multiculturalism Has Fared in South Korea Amid the Pandemic, retrieved from https://carnegieendowment.org/2020/12/15/how- 
multiculturalism-has-fared-in-south-korea-amid-pandemic-pub-83410. Accessed 15 July 2021.

Immunization Act (1994). Retrieved from http://www.japaneselawtranslation.go.jp/ law/detail_main?re=\&vm=02\&id=2964. Accessed 6 July 2021.

Japan Inc summoned to vaccinate its ranks, Strat Times (2020/07). retrieved from https://www.straitstimes.com/asia/east-asia/japan-inc-summoned-tovaccinate-its-ranks Accessed 6 July 2021.

Ministry of Health of South Korea (2021). Coronavirus Disease 19, retrieved from http://ncov.mohw.go.kr/en/?fbclid=IwAR12rHyzGtXIInbzCUzqKqW10305m0Uu UkiQxw0QS5qEEeT8TqsMiBCPtHU. Accessed 15 July 2021.

Mitch Shin (2021/04). As Vaccine Rollout Lags, South Koreans Sour on Government's COVID-19 Response. The Diplomat, retrieved from https://thediplomat.com/ 2021/04/as-vaccine-rollout-lags-south-koreans-sour-on-governments-covid-19response/. Accessed 15 July2021.

News Navigator: Why is Japan's coronavirus vaccination rate so low?,Mainichi News (2021/05), retrieved from https://mainichi.jp/english/articles/20210505/p2a/ 00m/0op/016000c. Accessed 4 July2021.

Osumi, M (2020/06). Japan softens re-entry ban that left foreign residents stranded. Japan Times, retrieved from https://www.japantimes.co.jp/news/2020/06/04/ national/japan-softens-re-entry-ban-foreign-residents/. Accessed 15 July2021.

Our World in Data (2021).Coronavirus (COVID-19) Vaccinations, retrieved from https://ourworldindata.org/covid-vaccinations?country=OWID_WRLAccessed 7 July 2021.

Pawnik, A (2021/07). Japończycy nie chcq Igrzysk, co zrobiq władze? [Japanese citizens do not want the Olympics to be held, how will the government react?] Puls Azji. Retrieved from http://pulsazji.pl/2021/07/06/igrzyska-olimpijskieodliczanie/. Accessed 6 July 2021.

Pawnik, A. (2020/04). Testy na koronawirusa - czego możemy się nauczyć od Korei Południowej? [COVID-19 testing - what can we learn from South Korea?]Puls Azji, retrieved from http://pulsazji.pl/2020/04/02/testy-na-koronawirusa/. Accessed 6 July 2021.

PM Suga's LDP, Komeito parties fail to win majority in Tokyo assembly, Kyodo News (2021/07), retrieved from https://english.kyodonews.net/news/2021/07/8dd 72dbba756-voting-under-way-in-tokyo-assembly-election.html. Accessed 5 July 2021. 
Press Conference by the Prime Minister: Opening Statement. (February 29, 2020), retrieved from https://japan.kantei.go.jp/98_abe/statement/202002/_00002. html. Accessed 15 July 2021.

SangmiChaHyonhee Shin (2021/07).S.Korea COVID-19 vaccine rollout grinds to halt as new cases hit record high. Reuters, retrieved from https://www.reuters.com/ world/asia-pacific/skorea-reports-new-coronavirus-cases-top-1000-7thstraight-day-2021-07-13/. Accessed 15 July2021.

South Korean companies, including Samsung Group and LG, offer employees COVID19 vaccines at work. Telecom (2021/07), retrieved from https://telecom. economictimes.indiatimes.com/news/south-korean-companies-includingsamsung-group-and-lg-offer-employees-covid-19-vaccines-at-work/83945539. Accessed 6 July 2021.

Steem, E. (2021/07). Here's the tentative timeline of Japan's Covid-19 vaccination programme. TimeOut, retrieved from https://www.timeout.com/tokyo/news/ heres-the-tentative-timeline-of-japans-covid-19-vaccination-programme012021. Accessed 4 July 2021.

Tokyo reports 570 new COVID-19 cases Thursday as experts warn of rebound. Japan Times (2021/06), retrieved from https://www.japantimes.co.jp/news/2021/ 06/24/national/japan-virus-cases-tokyo-june-24. Accessed 4 July2021.

Tracking Coronavirus Vaccinations Around the World, New York Times (2021/07). retrieved from https://www.nytimes.com/interactive/2021/world/covidvaccinations-tracker.html. Accessed 6 July 2021.

Ujek, J. (2020/08). Korea Południowanaszczycieprognozywzrostugospodarczego OECD [South Korea at the top of the OECD economic rankings]Puls Azji, retrieved from http://pulsazji.pl/2020/08/12/korea-poludniowa-szczycieprognozy-wzrostu-gospodarczego-oecd/. Accessed 15 July 2021.

Updates on COVID-19 in Tokyo.Tokyo Metropolitan Government (2021), retrieved from https://stopcovid19.metro.tokyo.lg.jp/en. Accessed 4 July 2021.

独立行政法人中小企業基盤整備機構 (2021), retrieved fromhttps://www.smrj.go.jp/english/about/. Accessed 7 July 2021. 